\title{
Emerging role of microRNAs in the treatment of hepatocellular carcinoma
}

This article was published in the following Dove Press journal:

Gastrointestinal Cancer: Targets and Therapy

14 May 2015

Number of times this article has been viewed

\section{Elisa Callegari' \\ Marco Domenicali ${ }^{2}$ \\ Laura Gramantieri ${ }^{3}$ \\ Massimo Negrini' \\ Silvia Sabbioni ${ }^{4}$}

'Department of Morphology, Surgery and Experimental Medicine, University of Ferrara, Ferrara, ${ }^{2}$ Department of Medical and Surgical Sciences, Alma Mater Studiorum University of Bologna, ${ }^{3}$ Center for Applied Biomedical Research, S OrsolaMalpighi University Hospital, Bologna, ${ }^{4}$ Department of Life Sciences and Biotechnology, University of Ferrara, Ferrara, Italy

Correspondence: Silvia Sabbioni Department of Life Sciences and Biotechnology, University of Ferrara, Via Luigi Borsari 46, 44I2I Ferrara, Italy Email sbs@unife.it

Massimo Negrini

Department of Morphology, Surgery and Experimental Medicine, University of Ferrara, Via Luigi Borsari 46, 44I2I

Ferrara, Italy

Email ngm@unife.it
Abstract: Hepatocellular carcinoma is the third leading cause of cancer deaths worldwide. Currently available curative options, such as surgery and transplantation, are not available to patients with advanced stages of disease. Among the potential new treatments being investigated are microRNA (miRNA)-based therapies. A number of preclinical studies have reported antitumor activities of miRNA mimics or anti-miRNA molecules. Optimal in vivo delivery of miRNA molecules is crucial to their action. To this end, significant progress has been made in the development of nanoparticles for in vivo delivery of miRNA molecules. Delivery of these molecules, alone or in combination with other drugs, promises to open new possibilities for therapeutic approaches to hepatocellular carcinoma.

Keywords: hepatocellular carcinoma, microRNA, nanocarriers, therapy

\section{Introduction}

Hepatocellular carcinoma (HCC) is the most common primary liver cancer and the third leading cause of cancer-related deaths worldwide. ${ }^{1}$ In $80 \%-90 \%$ of cases, HCC arises on a background of cirrhosis, ${ }^{2}$ a chronic and diffuse hepatic disease that results from continuous liver injury and regeneration. ${ }^{3}$ The prevalent risk factors for HCC include hepatitis $\mathrm{B}$ and $\mathrm{C}$ infection and alcohol consumption, which are also the main causes of liver cirrhosis. Other risk factors include exposure to aflatoxin B1 and vinyl chloride, tobacco smoking, diabetes, and genetic disorders such as hemochromatosis and alpha- 1 antitrypsin deficiency. ${ }^{4-9}$

The molecular mechanisms of liver tumorigenesis have been studied, and genetic and epigenetic alterations are reported to dysregulate several important signaling pathways, ${ }^{10-13}$ such as the RAS-mitogen-activated protein kinase and the PI3K/AKT/ PTEN signaling pathways, activated by epidermal growth factor, hepatocyte growth factor, platelet-derived growth factor, vascular endothelial growth factor, and fibroblast growth factor. Dysregulation leads to proliferation, cell survival, sustained angiogenesis, invasion, and metastasis. Activation of the $\mathrm{Wnt} / \beta$-catenin signaling pathway has also been observed, leading to deregulation of cell proliferation, differentiation, and stemness. ${ }^{14-18}$ Several cell cycle regulators, including RB1, cyclin-dependent kinases, cyclins, and cyclin-dependent kinase inhibitors, are aberrantly expressed in HCC, contributing to cell proliferation, while altered expression of BCL2 family members and other genes such as IAP and PTEN contribute to disruption of apoptosis. ${ }^{10}$ Recurrent mutations in the MLL family of histone methyltransferases are also reported to result in alteration of chromatin remodelers. ${ }^{13}$ 
Several therapeutic approaches are used nowadays for the management of patients with HCC. According to the Barcelona Clinic Liver Cancer staging system, ${ }^{19}$ potential curative treatment of eligible patients with early-stage $\mathrm{HCC}$ consists of resection, percutaneous ablation, and liver transplantation. ${ }^{10}$ Transarterial chemoembolization was shown to provide survival benefits in patients with intermediate-stage $\mathrm{HCC},{ }^{20,21}$ but is not curative. ${ }^{22}$ The prognosis of advanced HCC remains poor, since traditional chemotherapy agents have proven to be marginally effective or even toxic because of limited liver function. A therapeutic option for advanced HCC was offered by the multikinase inhibitor sorafenib, the effectiveness of which in increasing time to progression and overall survival was demonstrated by the SHARP trial in 2008 and confirmed in the Asia-Pacific region trial in 2009..$^{23,24}$ Sorafenib is active against several kinases, such as RAF-1, BRAF, vascular endothelial growth factor receptor 2, plateletderived growth factor receptor, and c-Kit receptors. ${ }^{25}$ This drug displays antiangiogenic and antiproliferative activity for numerous targets.

Nevertheless, resistance to sorafenib after the initial response arises in all patients, and several alternative agents, either alone or in combination with sorafenib, have been investigated in randomized controlled Phase III clinical trials. A combination of transarterial chemoembolization and sorafenib was shown to further improve survival rates in patients with advanced HCC. ${ }^{26-28}$ In contrast, the combination of sorafenib and the epidermal growth factor receptor inhibitor erlotinib did not demonstrate advantages over sorafenib alone (SEARCH trial, ClinicalTrials identifier NCT00901901). The combination of sorafenib and the histone deacetylase inhibitor resminostat is currently being evaluated in patients who are refractory to sorafenib monotherapy (ClinicalTrials identifier NCT00943449). ${ }^{29}$ Evaluation of other molecular targeted agents as a secondline treatment showed unsatisfactory results; both the mTOR inhibitor everolimus ${ }^{30}$ (EVOLVE, ClinicalTrials identifier NCT01035229) and the multikinase inhibitor brivanib ${ }^{31}$ failed to show survival benefits in patients who did not respond to sorafenib. Similarly, in first-line therapy, alternative multitargeted tyrosine kinase inhibitors (sunitinib, brivanib) conferred no survival benefits compared with sorafenib in the treatment of advanced HCC. ${ }^{32,33}$

Several limits have been identified in the settings of recent clinical trials and corrective actions proposed to reduce the risk of trial failure. ${ }^{34}$ In particular, better selection of enrolled patients, who reflect the molecular and clinical heterogeneity of the disease, has been indicated as a requirement for the correct design of future studies. To this end, despite improvements in the knowledge of the signal pathways involved in HCC, reliable biomarkers for "molecular patient stratification" are lacking and a need exists to identify the main drivers of hepatocarcinogenesis and matched active agents.

Despite awareness of the several signaling pathways involved in HCC, the majority of molecular targeted agents investigated so far in Phase III clinical trials in HCC are antiangiogenic molecules, and therapies that are able to affect multiple targets or different pathways could be more effective. In this context, microRNA (miRNA)-regulatory molecules that are individually able to affect multiple cellular pathways and play a key role in the control of several cancer genes are worth exploring.

\section{Involvement of miRNA in HCC}

The role of miRNAs in carcinogenesis has been extensively studied during the last decade. The expression of a number of miRNAs was found to be frequently altered in cancer cells, where miRNAs could disturb functions associated with control of proliferation, apoptosis, differentiation, angiogenesis, invasion, and metastasis. ${ }^{35}$ The abnormal expression of several miRNAs has also been demonstrated in HCC (Table 1). In some cases, hepatitis viruses were indicated to have a role in dysregulation of cellular miRNA. Hepatitis B virus messenger RNAs, containing an miR-122 complementary site, could act as a sponge that is able to sequester endogenous miR-122, ${ }^{36}$ thus lowering the levels of active miR-122. Hbx protein decreases levels of several tumor suppressor miRNAs, such as miR-34 and let-7, ${ }^{37}$ while HBx RNA directly downregulates miR-15a and miR-16-1..$^{38}$ Moreover, upregulated gene, upregulation of which is induced by HBx, could induce miR-148a overexpression and promote cell cycle progression and cell migration. ${ }^{39,40}$ The mechanisms of miRNA deregulation by hepatitis $\mathrm{C}$ virus have been less extensively studied. ${ }^{41} \mathrm{MiR}-141$ upregulation, which has been described in hepatitis $\mathrm{C}$ virus-infected human hepatocytes in vitro, causes the depletion of DLC-1 protein, a tumor suppressor frequently deleted in $\mathrm{HCC} .{ }^{42}$

Animal models based on miRNAs have confirmed their role in tumorigenesis, both in hematopoietic diseases ${ }^{43-46}$ and in solid tumors, such as HCC, ${ }^{47-49}$ thereby allowing preclinical studies based on the inhibition or restoration of miRNA (see Callegari et $\mathrm{al}^{50}$ for a comprehensive review, and Table 2).

The altered expression of miRNAs in HCC was further investigated to assess their importance as molecular markers for the prognostic stratification of HCC (Table 3). Recently, Yin et al conducted a meta-analysis of several 
Table I microRNAs with consistently deregulated expression in human hepatocellular carcinoma

\begin{tabular}{|c|c|c|c|}
\hline miRNA & Genome location & Expression in HCC & Targets \\
\hline let-7g & 3: 52302294-52302377 (-) & Down & BCL2LI, COLIA2 \\
\hline miR-I & 20: $611151513-61151583(+)$ & Down & MET, FOXPI, HDAC4 \\
\hline miR-23b & 9: $97847490-97847586(+)$ & Down & UPA, MET \\
\hline miR-26a & 3: 380I0895-380I097। (+) & Down & CCND2, CCNE \\
\hline miR-29 & 7: $13056 \mid 506-130561569(-)$ & Down & BCL2, MCLI \\
\hline miR-34a & I: $921 \mid 727-9211836(-)$ & Down & MET \\
\hline miR-I0I & I: 65524|I7-65524I9| (-) & Down & MCLI, FOS \\
\hline miR-I 22 & |8: 56||8306-56||8390 (+) & Down & CCNGI, SRF, IGFIR, BCL2L2, ADAMI0, ADAMI7 \\
\hline miR-I24 & 8: 9760898-9760982 (-) & Down & CDK6, VIM, SMYD3, IQGAPI \\
\hline miR-I25a & 19: 52196507-52196592(+) & Down & BMF, ERBB2, ERBB3 \\
\hline miR-125b & II: $121970465-121970552(-)$ & Down & \\
\hline miR-I30a & II: $5740867 \mid-57408759(+)$ & Down & ATXNI, PPAR $\gamma$ \\
\hline miR-139 & II: 72326I07-72326I74 (-) & Down & RHOK2 \\
\hline miR-I45 & 5: $1488|0209-| 488 \mid 0296(+)$ & Down & FSCNI, IRSI, STATI, YES, MYC, ESRI, KLF4, OCT4, SOX2, MUCI \\
\hline miR-I50 & 19: 50004042-50004|25 (-) & Down & EGR2 \\
\hline miR-193b & 16: |4397824-14397906 (+) & Down & MCLI \\
\hline miR-195 & 17: 6920934-6921020 (-) & Down & CCNDI, CDK6, E2F3 \\
\hline miR-199a-I & 19: $10928102-10928172(-)$ & Down & KRT7, SET, IKBKB, MAPKI, MET, HESI, SmadI, HIFIA \\
\hline miR-199a-2 & I: 172|| $3675-|72| 13784(-)$ & Down & \\
\hline miR-199b & 9: $131007000-131007109(-)$ & Down & \\
\hline miR-200a & I: II03243-II $03332(+)$ & Down & ZEBI, ZEB2, beta-catenin \\
\hline miR-200b & I: I I02484-I I02578 (+) & Down & \\
\hline miR-223 & $X: 652387 \mid 2-65238821(+)$ & Down & Stathmin I \\
\hline miR-375 & 2: $219866367-219866430(-)$ & Down & YAP \\
\hline miR-602 & 9: |4073287|-|40732968 (+) & Down & RASSFIA \\
\hline miR-17-5p & 13: 92002859-92002942 (+) & Up & $\begin{array}{l}\text { NCOA3, E2FI, BCL2LI I, CDKNIA, RBL2, MAPKI4, STAT3, CCLI, } \\
\text { DNAJC27, FBXO3I, GPRI 37B, NPAT, OBFC2A, RABI2, YESI, } \\
\text { ZNFXI, FNI, FNDC3A }\end{array}$ \\
\hline miR-I8a & 13: 92003005-92003075 (+) & $U_{p}$ & NR3CI, CTGF, ESRI \\
\hline miR-92a & 13: $92003568-92003645(+)$ & $U_{p}$ & HIFIA, STAT3, CDKNIA, MAPKI4, ZBTB7A, E2FI, E2F2, E2F3 \\
\hline miR-106-25 & 7: 99691616-99691697 (-) & $U_{p}$ & CDKNIA, BIM \\
\hline miR-2I & 17: 579|8627-579|8698(+) & Up & $\begin{array}{l}\text { FasL, SERPINB5, PDCD4, TIMP3, SPRY2, LRRFIPI, RECK, PTEN, } \\
\text { BTG2, Peli I, HNRPK, TP63, MARCKS, TPMI }\end{array}$ \\
\hline miR-30d & 8: $1358|7| 19-135817 \mid 88(-)$ & Up & Galphai2 \\
\hline miR-|5I & 8: $|4| 742663-|4| 742752(-)$ & Up & RhoGDIA \\
\hline miR-I8Ib-I & I: |98828002-|98828III (-) & Up & CDX2, GATA6, NLK, TIMP3 \\
\hline miR-135a & 3: 52328235-52328324 (-) & $U_{p}$ & APC \\
\hline $\begin{array}{l}\text { miR-22I/ } \\
\text { miR-222 }\end{array}$ & $X: 45605585-45605694(-)$ & Up & $\begin{array}{l}\text { BMF, CDKNIB, CDKNIC, ESRI, ICAMI, KIT, PTEN, TIMP3, MET, } \\
\text { DDIT4, FOXO3 }\end{array}$ \\
\hline miR-224 & $X: 15|127050-15| 127 \mid 30(-)$ & Up & CD40, CDC42, CXCR4, KLKI0, Smad4, API5 \\
\hline miR-373 & 19: 54291959-54292027 (+) & Up & MBD2, CD44, LATS2 \\
\hline miR-483-3p & II: 2I55364-2I55439 (-) & Up & $\mathrm{BBC} 3$ \\
\hline
\end{tabular}

Note: Copyright (C) 20II. Dove Medical Press. Adapted from Negrini M, Gramantieri L, Sabbioni S, Croce CM. microRNA involvement in hepatocellular carcinoma. Anticancer Agents Med Chem. 20I I; I (6):500-521. ${ }^{35}$

Abbreviation: HCC, hepatocellular carcinoma

studies, showing that multigroup analysis on miRNA panels could give better diagnostic accuracy than single miRNAs. ${ }^{51}$ Moreover, abnormal levels of miRNAs were also found in the serum or plasma of HCC patients in comparison with those in healthy subjects, thus also suggesting a potential role for miRNAs as circulating biomarkers (Table 4)..$^{35,52-54}$

\section{miRNAs as therapeutic agents}

Given the importance of miRNAs in several aspects of tumorigenesis, their therapeutic value has also been investigated.
The inhibition of miRNA expression in vivo was for the first time shown to be feasible by the intravenous administration of single-stranded anti-miR-122 "antagomir" oligonucleotides in mice. ${ }^{55}$ Subsequently, the safety of a locked nucleic acidmodified anti-miR-122 was assessed in nonhuman primates by showing the absence of toxicity or histopathological changes in the liver after administration of this molecule. ${ }^{56}$ Following these studies, a locked nucleic acid-modified anti-miR-122 (miravirsen, SPC3649, Santaris Pharma, Copenhagen, Denmark) entered into clinical trials for the 
Table 2 microRNA-based therapies in preclinical models

\begin{tabular}{|c|c|c|c|c|c|}
\hline miRNAs & Mouse model & Tumor & Method & Delivery system & Reference \\
\hline miR-22I & Xenograft & Prostate carcinoma & miRNA inhibition & Antagomir & 108 \\
\hline miR-22I & Xenograft & Melanoma & miRNA inhibition & Antagomir oligonucleotide & 109 \\
\hline miR-22I & Xenograft & Multiple myeloma & miRNA inhibition & mirVana custom inhibitor & 110 \\
\hline miR-22I & Orthotopic model & $\mathrm{HCC}$ & miRNA inhibition & $\begin{array}{l}\text { Cholesterol-modified isoform } \\
\text { of anti-miR-22I }\end{array}$ & 66 \\
\hline miR-22I & TG-22I & $\mathrm{HCC}$ & miRNA inhibition & anti-miRNA oligonucleotide & 47 \\
\hline miR-494 & tet-o-MYC; LAP-tTA & $\mathrm{HCC}$ & miRNA inhibition & miR-494 anti-miR & III \\
\hline miR-I43 & Xenograft & Colorectal cancer & miRNA replacement & $\begin{array}{l}\text { Chemically modified } \\
\text { benzene(B)-pyridine(P)-analog } \\
\text { at the } 3^{\prime} \text {-overhang region }\end{array}$ & 112 \\
\hline miR-I0I & Xenograft & $\mathrm{HCC}$ & miRNA replacement & RNA duplex & 113 \\
\hline miR-29b & Xenograft & $\mathrm{HCC}$ & miRNA replacement & $\begin{array}{l}\text { 2'-O-methyl-modified } \\
\text { oligoribonucleotides }\end{array}$ & 114 \\
\hline miR-199a/b-3p & Xenograft & $\mathrm{HCC}$ & miRNA replacement & AAV & 68 \\
\hline miR-199a/b-3p & Xenograft & $\mathrm{HCC}$ & miRNA replacement & Lentivirus & 115 \\
\hline $\operatorname{miR}-375$ & Xenograft & $\mathrm{HCC}$ & miRNA replacement & $\begin{array}{l}\text { Cholesterol-conjugated } \\
\text { 2'-O-methyl-modified miRNA }\end{array}$ & 116 \\
\hline miR-3I & Xenograft & Metastasis & miRNA replacement & $\begin{array}{l}\text { dox-repressible modified } \\
\text { miR-3I miRNA sponge } \\
\text { vector system }\end{array}$ & 117 \\
\hline $\operatorname{miR}-34 a$ & Xenograft & Multiple myeloma & miRNA replacement & Lentivirus & 118 \\
\hline Let-7 & $\begin{array}{l}\text { Xenograft; } \\
\text { LSL-K-ras GI2D }\end{array}$ & NSCLC & miRNA replacement & $\begin{array}{l}\text { Synthetic miRNAs complexed } \\
\text { with siPORT amine; lentivirus }\end{array}$ & 119 \\
\hline miR-26a & tet-o-MYC; LAP-tTA & $\mathrm{HCC}$ & miRNA replacement & AAV & 67 \\
\hline miR-I 22 & tet-o-MYC; LAP-tTAT; & $\mathrm{HCC}$ & miRNA replacement & AAV & 48 \\
\hline miR-422 & $\begin{array}{l}\text { Xenograft; DEN-induced } \\
\text { HCC mouse model }\end{array}$ & $\mathrm{HCC}$ & miRNA replacement & Oligo mimics; lentivirus & 120 \\
\hline Let-7 & Xenograft & $\begin{array}{l}\text { Colon and lung } \\
\text { carcinoma }\end{array}$ & Oncolytic virus & Vesicular stomatitis virus & $|2|$ \\
\hline Let-7 & Xenograft & $\begin{array}{l}\text { Lung and pancreatic } \\
\text { carcinoma }\end{array}$ & Oncolytic virus & Vaccinia virus & 122 \\
\hline Let-7 & Xenograft & $\mathrm{HCC}$ & Oncolytic virus & Adenovirus & 73 \\
\hline miR-I22 & Xenograft & $\mathrm{HCC}$ & Oncolytic virus & Adenovirus & 123 \\
\hline miR-I 22 & Xenograft & Lung cancer & Oncolytic virus & Adenovirus & 124 \\
\hline miR-I43; miR-I 45 & Xenograft & Prostate cancer & Oncolytic virus & Herpes simplex virus & 125 \\
\hline miR-I22; miR-I24; let-7 & Xenograft & $\mathrm{HCC}$ & Oncolytic virus & Herpes simplex virus & 126 \\
\hline miR-7 & Xenograft & Gliomas & Oncolytic virus & Measles virus & 127 \\
\hline miR-I33a and miR-206 & Xenograft & $\begin{array}{l}\text { Prevents fatal } \\
\text { myositis }\end{array}$ & Oncolytic virus & Coxsackievirus A2I & 128 \\
\hline miR-199 & Xenograft; TG-22I & $\mathrm{HCC}$ & Oncolytic virus & Adenovirus & 74 \\
\hline miR-I24 & $\begin{array}{l}\text { Orthotopic model of } \\
\text { primary human GBM }\end{array}$ & Glioma & Oncolytic virus & Herpes simplex virus & 129 \\
\hline $\begin{array}{l}\text { miR-124, miR-128, } \\
\text { miR-146b and miR-218 }\end{array}$ & Xenografts & Glioma & Oncolytic virus & Adenovirus & 130 \\
\hline
\end{tabular}

Abbreviations: HCC, hepatocellular carcinoma; DEN, diethylnitrosamine; NSCLC, non-small cell lung cancer; AAV, adeno-associated viruses; GBM, glioblastoma multiforme.

treatment of hepatitis $\mathrm{C}$ virus infection, ${ }^{57}$ since efficient replication of this virus in the liver depends on miR-122 expression. ${ }^{58-62} \mathrm{~A}$ combination approach has also been proposed for the treatment of hepatitis $\mathrm{C}$ virus infection through the use of antiviral drugs (telaprevir and ribavirin) with miRNA-based therapy (miravirsen, ClinicalTrials identifier NCT01872936). ${ }^{63}$ Similarly, since hepatitis B virus affects miRNA cellular levels in several ways, new miRNA-based approaches could represent a promising area of investigation for treatment of hepatitis B virus infection and reduction of the risk of HCC. ${ }^{37}$

Although modulation of hepatitis $\mathrm{C}$ virus by miravirsen has potential implications for the prevention of $\mathrm{HCC}$, other anti-miRNA molecules have been evaluated in preclinical studies (Table 2). In particular, considering the role of miR-221 in HCC as a tumor promoter, ${ }^{64,65}$ anti-miR-221 molecules were used in murine models of HCC, where their therapeutic potential was demonstrated. ${ }^{47,66}$ Other studies 
Table 3 miRNA alterations with potential prognostic impact in patients with HCC

\begin{tabular}{|c|c|c|c|}
\hline miRNAs & Molecular alteration & Clinical significance & References \\
\hline 20 miRNAs & Signature & Venous metastasis, overall survival & $|3|$ \\
\hline 19 miRNAs & Signature & Poor survival & 132 \\
\hline $\begin{array}{l}\text { miR-19a, miR-886-5p, miR-126, } \\
\text { miR-223, miR-24 and miR-147 }\end{array}$ & Signature & $\begin{array}{l}\text { Predictor of overall survival and recurrence-free survival } \\
\text { after LT }\end{array}$ & 133 \\
\hline miR-26a & Downregulation & Poor survival & 134 \\
\hline miR-I 22 & Downregulation & Gain of metastatic properties & 135,136 \\
\hline miR-I22 & Downregulation & Early recurrence & 96 \\
\hline Let-7 members & Downregulation & Early recurrence & 137 \\
\hline miR-199a-3p & Downregulation & Reduced time to recurrence & 93 \\
\hline miR-199b-5p & Downregulation & Poor overall survival and progression-free survival rates & 138 \\
\hline miR-I0I & Downregulation & Advanced tumor progression, poor prognosis & 139 \\
\hline miR-125a & Upregulation & Better survival & 140 \\
\hline miR-92, miR-20, miR-I8 & Upregulation & Poor differentiation & $|4|$ \\
\hline miR-372 & Upregulation & Advanced TNM stage & 142 \\
\hline miR-22I & Upregulation & Multinodularity; reduced time to recurrence & 143 \\
\hline miR-22I & Upregulation & Gain of metastatic properties & 144 \\
\hline miR-22I & Upregulation & High tumor capsular infiltration & 145 \\
\hline miR-17-5p & Upregulation & Multiple tumor nodules; vein invasion; shortened overall survival & 146 \\
\hline miR-I55 & Upregulation & High recurrence and poor prognosis following OLT & 147 \\
\hline miR-203 & Upregulation & Good prognosis & 148 \\
\hline miR-18 & Upregulation & Poor prognosis & 149 \\
\hline miR-20a & Downregulation & $\begin{array}{l}\text { Poor survival and tumor recurrence in } \mathrm{HCC} \text { patients who } \\
\text { underwent } \mathrm{LT}\end{array}$ & 150 \\
\hline miR-I85 & Downregulation & Short overall survival and time to recurrence in early-stage HCC & 151 \\
\hline miR-I46 & Downregulation & $\begin{array}{l}\text { Related to clinical TNM stage, metastasis, portal vein tumor } \\
\text { embolus, and multiple tumor nodes }\end{array}$ & 152 \\
\hline miR-139 & Downregulation & $\mathrm{HCC}$ risk association and short-term survival & 153 \\
\hline $\operatorname{miR}-25$ & Upregulation & Poor prognosis & 154 \\
\hline
\end{tabular}

Note: Copyright @ 20I I. Dove Medical Press. Adapted from Negrini M, Gramantieri L, Sabbioni S, Croce CM. microRNA involvement in hepatocellular carcinoma. Anticancer Agents Med Chem. 201 I; I (6):500-521; $3^{5}$ and Copyright (C 2013. Dove Medical Press. Callegari E, Elamin BK, Sabbioni S, Gramantieri L, Negrini M. Role of microRNAs in hepatocellular carcinoma: a clinical perspective. Onco Targets Ther. 2013;6:I I67-1 I $78 .{ }^{54}$

Abbreviations: HCC, hepatocellular carcinoma; TNM, tumor node metastasis; LT, liver transplant; OLT, orthotopic liver transplant.

have also demonstrated the therapeutic efficacy of the restoration of tumor suppressor miRNAs that are underexpressed in cancer. miR-26a, ${ }^{67}$ miR-122, ${ }^{48}$ and miR-199a ${ }^{68}$ could effectively and significantly reduce tumor growth by use of adenoassociated viruses as delivery vectors in animal models. A Phase I clinical trial was initiated in 2013 to evaluate the safety of a liposome-formulated miR-34 mimic, MRX34 (Mirna Therapeutics, Austin, TX, USA), in patients with primary liver cancer or liver metastases from other cancers (ClinicalTrials identifier NCT01829971). ${ }^{63,69}$ Recently, Kelnar et al established the pharmacokinetic profile of MRX34 in nonhuman primates, providing useful data on the calculation of the first dose in clinical trials of MRX34. ${ }^{70}$

An additional potential option for miRNA-based therapeutics resides in their use for the control of oncolytic virus replication. On the basis of a first example of a conditional replicative adenovirus regulated by miR-122 to circumvent liver toxicity, ${ }^{71,72}$ other oncolytic viruses were developed, including miRNA let-7-dependent ${ }^{73}$ and miR-199-dependent ${ }^{74}$ conditional replicative adenoviruses. Because of the differential expression of these miRNAs between normal liver cells and liver cancer cells, these viruses were able to replicate in HCC tumor cells but not in normal liver cells, did not produce significant toxicities in normal tissues, and, importantly, have shown the ability to inhibit tumor growth in vivo. As reported in Table 2, a let-7-dependent adenovirus exhibited antitumor activity in an HCC xenograft model, and a miR-199-dependent conditional replicative adenovirus was able to control tumor growth both in an HCC xenograft model and in an $\mathrm{HCC}$ transgenic mouse. ${ }^{73,74}$ For more comprehensive reviews, see Callegari et al. ${ }^{50,54}$

\section{Nanotechnologies for in vivo delivery of miRNAs}

In addition to providing encouraging proofs of principle for the application of miRNA-based therapies, the miRNA studies described above revealed weaknesses of the approaches. Although several strategies have been adopted to increase biological stability (chemical modifications of the backbone, glycosylation, nucleic acid locking), limitations surfaced that were 
Table 4 Circulating microRNAs in liver diseases

\begin{tabular}{|c|c|c|c|c|}
\hline miRNAs & Sample & Clinical condition & Clinical value & References \\
\hline miR-I22 & Serum & $\begin{array}{l}\text { High levels in patients with HCC or chronic } \\
\text { hepatitis; lower levels in severe stage of fibrosis }\end{array}$ & $\begin{array}{l}\text { Biomarker for liver injury but not specific } \\
\text { for HCC; indicator of fibrosis progression } \\
\text { in } \mathrm{CHC} \text { infection; marker to distinguish } \\
\mathrm{CHC} \text { patients from healthy controls }\end{array}$ & $155-159$ \\
\hline miR-2I & $\begin{array}{l}\text { Serum/ } \\
\text { plasma }\end{array}$ & $\begin{array}{l}\text { High levels in patients with HCC or chronic hepatitis; } \\
\text { higher levels in patients with HCC than in patients } \\
\text { with chronic hepatitis and healthy volunteers }\end{array}$ & $\begin{array}{l}\text { Biomarker for liver injury but not specific } \\
\text { for HCC; biochemical marker for HCC }\end{array}$ & $156,160-162$ \\
\hline miR-223 & Serum & High levels in patients with $\mathrm{HCC}$ or chronic hepatitis & $\begin{array}{l}\text { Biomarkers for liver injury but not } \\
\text { specifically for HCC }\end{array}$ & 160 \\
\hline miR-885-5p & Serum & High levels in patients with $\mathrm{HCC}, \mathrm{LC}$, and $\mathrm{CHB}$ & $\begin{array}{l}\text { Complementary biomarker for the detection } \\
\text { and assessment of liver pathologies }\end{array}$ & 163 \\
\hline $\begin{array}{l}\text { miR-I6 } \\
\text { miR-34a }\end{array}$ & Serum & Higher levels in NAFLD patients than in controls & $\begin{array}{l}\text { Correlation with liver enzymes levels, fibrosis } \\
\text { stage, and inflammation activity; biomarkers } \\
\text { of diagnosis and histological disease severity } \\
\text { in patients with CHC or NAFLD }\end{array}$ & 156 \\
\hline miR-22I & Serum & $\begin{array}{l}\text { High levels correlated with tumor size, cirrhosis, } \\
\text { and tumor stage }\end{array}$ & $\begin{array}{l}\text { Predictive significance for prognosis } \\
\text { of } \mathrm{HCC} \text { patients }\end{array}$ & 162 \\
\hline $\begin{array}{l}\text { miR-I5b } \\
\text { miR-I30b }\end{array}$ & Serum & $\begin{array}{l}\text { Higher levels in tumors during the exploration phase } \\
\text { on resected tumor/adjacent non-tumor tissues; lower } \\
\text { levels after surgery }\end{array}$ & $\begin{array}{l}\text { Biomarker with clinical value for } \mathrm{HCC} \\
\text { screening }\end{array}$ & 164 \\
\hline $\begin{array}{l}\text { miR-20a } \\
\text { miR-92a }\end{array}$ & $\begin{array}{l}\text { Plasma/ } \\
\text { serum }\end{array}$ & $\begin{array}{l}\text { High levels in HCV-infected fibrosis patients compared } \\
\text { with healthy volunteers or non-HCV-associated liver } \\
\text { disease; higher levels in acute and chronic HCV-infected } \\
\text { patients as compared with healthy volunteers }\end{array}$ & $\begin{array}{l}\text { Biomarkers for early detection of } \mathrm{HCV} \\
\text { infection; miR-20a is a predictive } \\
\text { biomarker of HCV-mediated fibrosis }\end{array}$ & 165 \\
\hline $\operatorname{miR}-18 \mathrm{a}$ & Serum & $\begin{array}{l}\text { Higher levels in HBV patients with } \mathrm{HCC} \text { than } \\
\text { in healthy controls }\end{array}$ & $\begin{array}{l}\text { Non-invasive biomarker for HBV-related } \\
\text { HCC screening }\end{array}$ & 166 \\
\hline miR-17-5p & Serum & $\begin{array}{l}\text { Associated with metastasis status and TNM stages. } \\
\text { HCC patients with high expression of serum miR-17-5p } \\
\text { show a significantly shortened overall survival }\end{array}$ & $\begin{array}{l}\text { Biomarker for the prognostic prediction } \\
\text { of HCC patients }\end{array}$ & 38 \\
\hline miR-I0I & Serum & $\begin{array}{l}\text { Inverse correlation between serum miR-I0I levels } \\
\text { and tissue miR-IOI expression levels. High levels in } \\
\text { patients with HBV-related HCC versus healthy controls: } \\
\text { this increase correlated with hepatitis B surface antigen } \\
\text { positivity, HBV DNA levels, and tumor size }\end{array}$ & $\begin{array}{l}\text { Biochemical marker for monitoring } \\
\text { the progression of tumor development } \\
\text { in HBV-related HCC }\end{array}$ & 167 \\
\hline miR-I0I & Serum & $\begin{array}{l}\text { Serum miR-IOI levels were found to be significantly } \\
\text { downregulated in HBV-HCC patients compared with } \\
\text { HBV-LC patients, CHB patients, and healthy controls, } \\
\text { but were upregulated in HBV-LC patients compared } \\
\text { with CHB patients and healthy controls. Consistent } \\
\text { with the serum data, the expression of miR-IOI was } \\
\text { also upregulated and downregulated in the HBV-LC } \\
\text { and HBV-HCC tissue samples, respectively }\end{array}$ & $\begin{array}{l}\text { Non-invasive biomarker to differentiate } \\
\text { HBV-HCC from HBV-LC }\end{array}$ & 168 \\
\hline $\begin{array}{l}\text { miR-I25b-5p } \\
\text { and miR223-3p }\end{array}$ & Serum & $\begin{array}{l}\text { High levels of miR-I25b-5p in CHB, HBV-positive } \\
\text { cirrhosis, and HBV-positive HCC compared with } \\
\text { control group. Low levels of miR-223-3p were } \\
\text { detected in same comparisons }\end{array}$ & $\begin{array}{l}\text { Non-invasive biomarkers of HBV-positive } \\
\mathrm{HCC} \text { in very early disease, even at CHB } \\
\text { stage of liver disease }\end{array}$ & 169 \\
\hline $\begin{array}{l}\text { miR-I6, let-7f, } \\
\text { and miR-2I }\end{array}$ & Serum & $\begin{array}{l}\text { Low levels in patients with a tumor more than } 5 \mathrm{~cm} \\
\text { in diameter, correlated with clinical features such as } \\
\text { platelets and bilirubin. High levels of serum let-7f in } \\
\text { patients with a tumor more than } 5 \mathrm{~cm} \text { in diameter } \\
\text { and early recurrence. High levels of miR-2l in female } \\
\text { patients with HCC }\end{array}$ & $\begin{array}{l}\text { Potential indicators to estimate tumor } \\
\text { size or recurrence of HCC }\end{array}$ & 170 \\
\hline microRNA-2I & Serum & $\begin{array}{l}\text { High levels of miR-2I expression correlated } \\
\text { with cirrhosis and advanced tumor stage }\end{array}$ & $\begin{array}{l}\text { Potential biomarker for early detection of } \\
\text { HCC. No correlation of miR-2I expression } \\
\text { with other clinical features including age, } \\
\text { sex, and HBV infection }\end{array}$ & $17 \mid$ \\
\hline $\begin{array}{l}\mathrm{miR}-143 \text { and } \\
\mathrm{miR}-215\end{array}$ & Serum & $\begin{array}{l}\text { High levels in patients with chronic hepatitis } \\
\text { and HCC }\end{array}$ & $\begin{array}{l}\text { Valuable biomarkers for chronic hepatitis } \\
(\mathrm{HBV} \text { and } \mathrm{HCV} \text { ) and } \mathrm{HCC}\end{array}$ & 172 \\
\hline
\end{tabular}


Table 4 (Continued)

\begin{tabular}{|c|c|c|c|c|}
\hline miRNAs & Sample & Clinical condition & Clinical value & References \\
\hline $\begin{array}{l}\text { miR-200a, } \\
\text { miR-2I, } \\
\text { miR-I } 22 \text { and } \\
\text { miR-224-5p }\end{array}$ & Serum & $\begin{array}{l}\text { High levels of miR-200a, miR-2I, miR-I22, and } \\
\text { miR-224-5p in HCC following TACE was } \\
\text { associated with a decreased overall survival }\end{array}$ & $\begin{array}{l}\text { miR-200a may be a promising prognostic } \\
\text { biomarker in HCC patients. Patients with a } \\
\text { high risk of TACE treatment failure may benefit } \\
\text { from measurement of miR-200a in serum }\end{array}$ & 173 \\
\hline $\begin{array}{l}\text { miR-375 and } \\
\text { miR-199a-3p }\end{array}$ & Serum & $\begin{array}{l}\text { Low levels in HCC patients in comparison } \\
\text { with healthy controls }\end{array}$ & Potential biomarkers in early-stage HCC & 174 \\
\hline
\end{tabular}

Note: Copyright (C) 2013. Dove Medical Press. Adapted from Callegari E, Elamin BK, Sabbioni S, Gramantieri L, Negrini M. Role of microRNAs in hepatocellular carcinoma: a clinical perspective. Onco Targets Ther. 2013;6:1167-1 178. ${ }^{54}$

Abbreviations: HCC, hepatocellular carcinoma; CHC, chronic hepatitis C; CHB, chronic hepatitis B; LC, liver cirrhosis; NAFLD, non-alcoholic fatty liver disease; HCV, hepatitis C virus; HBV, hepatitis B virus; HBV-HCC, HBV-associated hepatocellular carcinoma; HBV-LC, HBV-associated liver cirrhosis; TACE, transarterial chemoembolization; TNM, tumor node metastasis.

related to stability, stimulation of the immune system, and offtarget effects; the need to find a solution thus became evident. The development of more effective delivery approaches was undertaken to improve the potential of miRNA-based therapies after their in vivo systemic administration.

Among the approaches investigated to improve in vivo delivery of drugs, the use of nanoparticles is of particular interest. Different types of nanoparticles exist, range between 20 and $200 \mathrm{~nm}$ in diameter, and are formulated with different materials, including lipids, polymers, and inorganic materials. ${ }^{75}$ First-generation formulations consisted of nanoparticles associated with anticancer drugs that were administered intravenously to carry the drug to the tumor through "passive tumor targeting". As a result of the pathophysiological differences between healthy and tumor-associated blood vessels and to the high production of mediators of permeability in tumors, these nanodrugs could accumulate in tumors through the enhanced permeability and retention effect. ${ }^{76}$

Nanoparticles have also been used to convey molecules such as DNA or RNA oligonucleotides to tumor cells. First studies proving the delivery of oligonucleotides reported the use of stable nucleic acid lipid particles. In a formulation based on cationic lipid nanoparticles (LNPs), the delivery of short interfering RNA (siRNA) antiapolipoprotein B and proprotein convertase subtilisin/kexin type 9 in mice and nonhuman primates was reported to inhibit hypercholesterolemia, with a rapid and dose-dependent gene silencing effect. ${ }^{77,78}$ Various additional formulations of nanoparticles were subsequently proposed to verify the possible use of oligonucleotides as anticancer agents. The main types of nanoparticles used for conveying siRNA and miRNA are cationic liposomes or positively charged polymers, such as polyethylenimine, or waterinsoluble polymers, such as poly-lactide-co-glycolide. ${ }^{79}$ For example, in a diethylnitrosamine-induced HCC mouse model, systemic administration of miR-124 through liposomes led to a reduction in tumor growth and tumor size via induction of apoptosis and deregulation of an miRNA/inflammatory feedback loop circuit involving hepatocyte nuclear factor 4 alpha $^{80}$ (see Table 5 for a list of nanocarrier formulations used in miRNA delivery). Trang et al have used neutral lipid emulsions to mediate the delivery of miR-let-7 and miR-34a in a non-small cell lung cancer model. The delivery of both miRNAs inhibited tumor growth, confirming their role as tumor suppressors and their therapeutic potential in the treatment of lung cancer. ${ }^{81}$ Hsu et al used modified cationic LNPs to convey miR-122 in a mouse model of HCC. After intravenous administration, miR-122 was found to accumulate in both normal and tumor liver cells; no toxicity or induced immune response was detected. Significant suppression of tumor growth related to a reduction in expression of molecular targets of miR-122 was also reported. ${ }^{82}$ Wang et al also recently discovered that the inclusion of an unsaturated fatty acid, called "helper lipid", in the formulation of LNPs significantly improved transport of miR-122, resulting in its accumulation in the liver. ${ }^{83} \mathrm{~A}$ formulation of cationic LNPs for the delivery of two different siRNAs, ie, anti-vascular endothelial growth factor and anti-kinesin spindle protein (ALN-VSP02), is currently in a Phase I clinical trial (ClinicalTrials identifiers NCT00882180 and NCT01158079) in patients with hepatic and extrahepatic tumors. The study showed that this formulation of LNP-siRNA is not toxic and is well tolerated. ${ }^{84}$

The delivery of nucleic acid molecules with nanoparticles has been improved by the addition of specific ligands (targeted nanodrugs). ${ }^{85}$ This approach made it possible to convey siRNAs/miRNAs to cancer cells that present specific receptors or antigens ("active tumor targeting"). An example of this strategy is given by miR-34, which is encapsulated in a liposome-polycation-hyaluronic acid nanoparticle formulation modified with a GC4 single-chain variable antibody fragment, a tumor-targeting human monoclonal antibody used against melanoma metastases. Systemic injection of miR-34 liposome-polycation-hyaluronic acid-modified nanoparticles in mice with metastasis of B16F10 melanoma cells in the lung significantly inhibited the growth of cancer cells 
Table 5 Representative nanocarrier delivery approaches for microRNA-based therapies in vivo

\begin{tabular}{|c|c|c|c|c|c|}
\hline miRNAs & Mouse model & Tumor & Method & Nanoparticle delivery system & Reference \\
\hline miR-2I & Xenograft & Multiple myeloma & miRNA inhibition & NLE-formulated synthetic oligo & 175 \\
\hline miR-I55 & mir-155 LSLLTA & B-cell lymphomas & miRNA inhibition & Anti-miR-loaded PLGA nanoparticles & 176 \\
\hline miR-296 & Xenograft & Angiogenesis & miRNA inhibition & cRGD-LPH-NP; AMOs & 177 \\
\hline miR-34 & Xenograft & Metastasis & miRNA replacement & $\begin{array}{l}\text { LPH NP-modified with GC4 single-chain } \\
\text { variable antibody fragment (scFv) }\end{array}$ & 86 \\
\hline miR-34 & Xenograft & Neuroblastoma & miRNA replacement & $\begin{array}{l}\text { Silica nanoparticles conjugated with } \\
\text { an antibody GD (2) }\end{array}$ & 87 \\
\hline $\operatorname{miR}-122$ & Xenograft & $\mathrm{HCC}$ & miRNA replacement & Cationic lipid nanoparticles & 82 \\
\hline miR-124 & $\begin{array}{l}\text { DEN-induced HCC } \\
\text { mouse model }\end{array}$ & $\mathrm{HCC}$ & miRNA replacement & Liposomes & 80 \\
\hline $\operatorname{miR}-34 a$ & $\begin{array}{l}\text { Kras }{ }^{\text {LLL-GI2D/+; }} \\
\operatorname{Trp} 53^{\text {LLL-RI } 72 \mathrm{H} /+}\end{array}$ & Lung adenocarcinoma & miRNA replacement & NLE particle-delivered miRNA mimic & 178 \\
\hline $\mathrm{miR}-29 \mathrm{~b}$ & Xenograft & NSCLC & miRNA replacement & Cationic lipoplexes & 179 \\
\hline $\begin{array}{l}\text { miR-34a; } \\
\text { let-7 }\end{array}$ & $\begin{array}{l}\text { Xenograft; } \\
\text { LSL-K-ras GI2D }\end{array}$ & NSCLC & miRNA replacement & NLE particle-delivered miRNA mimic & 81 \\
\hline $\operatorname{miR}-29 b$ & Engraft & AML & miRNA replacement & $\begin{array}{l}\text { Transferrin-conjugated anionic } \\
\text { lipopolyplex nanoparticles (TF-Np-miR) }\end{array}$ & 180 \\
\hline $\begin{array}{l}\operatorname{miR} 145 \\
\text { miR-33 }\end{array}$ & Xenograft & Colon carcinoma & miRNA replacement & PEI/miRNA complex & 181 \\
\hline $\begin{array}{l}\text { miR-I } 43 \\
\text { miR-I } 45\end{array}$ & Xenograft & Colorectal cancer & miRNA replacement & $\begin{array}{l}\text { Synthetic miRNA encapsulated } \\
\text { with cationic liposomes (LipoTrust) }\end{array}$ & 182 \\
\hline miR-7 & Xenograft & Angiogenesis; glioblastoma & miRNA replacement & $\begin{array}{l}\text { Integrin-targeted biodegradable } \\
\text { polymeric nanoparticles }\end{array}$ & 183 \\
\hline
\end{tabular}

Abbreviations: AMOs, anti-miRNA oligonucleotides; HCC, hepatocellular carcinoma; DEN, diethylnitrosamine; NSCLC, non-small cell lung cancer; AML, acute myeloid leukemia; NLE, neutral lipid emulsion; PLGA, poly-lactide-co-glycolide; NP, nanoparticles; PEl, polyethylenimine; LPH, liposome-polycation-hyaluronic acid.

without inducing toxicity. ${ }^{86}$ The same miR-34, encapsulated in silica nanoparticles conjugated with antibody anti-GD(2), a cell surface antigen disialoganglioside, was specifically conveyed to neuroblastoma tumor cells in a murine orthotopic xenograft model; there was a consequent significant decrease in tumor growth, increased apoptosis, and reduced vascularization. ${ }^{87}$

In addition to nanotechnology approaches for the delivery and restoration of miRNA levels in target cells, nanoparticles have also been used for transporting anti-miRNAs. For example, interfering nanoparticles have been designed and prepared to convey a chemically stabilized anti-miR-122 molecule into the mouse liver. These nanoparticles present amino acids on their surface, with an excellent binding affinity for negatively charged molecules, such as siRNA or miRNA. ${ }^{88,89}$ This approach led to the specific silencing of miR-122 in the liver without inducing an immune response, and suggested its potential use for the delivery of anti-miRNAs or miRNA mimics for therapy against HCC. An optimized 2'-OMe-4'-modified thioribonucleoside antimiR-122 has been conveyed to the mouse liver by using liposomes conjugated with a pH-sensitive cationic lipid, YSK05 (YSK05-MEND), ${ }^{90}$ which proved to be effective in inhibiting miR-122 at low doses. ${ }^{91}$ Another formulation based on LNPs conjugated with a ligand for the asialoglycoprotein receptor and peptide gramicidin A has recently been developed to inhibit miR-155. Its intravenous injection has allowed the efficient diffusion of molecules of anti-miR155 to the liver of wild-type mice, leading to a preferential accumulation of anti-miR-155 in hepatocytes and upregulation of miR-155 target genes. ${ }^{92}$

To date, no studies have compared different formulations in the same preclinical model or with the same molecule, so a comparative assessment of the different formulations in terms of efficacy and safety of delivery is difficult. However, data emerging from recent studies strongly suggest the usefulness of nanotechnology approaches for implementing miRNAbased therapeutics against HCC.

\section{miRNA and chemoresistance}

A potentially important area of investigation and application of miRNA-based therapies is represented by resistance to drugs. Drug resistance is one of the main obstacles to the treatment of tumors, as most patients become insensitive to therapies that have until then been effective. This insensitivity causes treatment failure and tumor relapse.

Altered levels of miRNAs in cancer may significantly affect the sensitivity to chemotherapy drugs. For example, the sensitivity of HCC cells to apoptosis induced by doxorubicin is significantly influenced by two miRNAs, miR-199a-3p and 
miR-26b. ${ }^{93,94}$ Evaluation of miRNA levels that predict the response to therapy could be needed to set the correct treatment for a patient. To overcome acquired resistance to sorafenib, for example, the synergistic combination with other molecules may potentially represent an improvement in therapeutic options. In fact, it has been shown that enforced expression of miR-122 sensitizes HCC cells to sorafenib ${ }^{95}$ or doxorubicin, ${ }^{96}$ while restoration of miR-34a in HCC cells treated with sorafenib increased apoptosis induced by the drug. ${ }^{97}$

In this context, nanotechnology approaches may represent a useful and important aid. Nanoparticle formulations combining chemotherapy drugs and siRNAs have been proposed to prevent drug resistance, for example, the use of anti-Myc combined with doxorubicin against fibrosarcoma cells in vitro and in vivo, or anti-Bcl 2 combined with doxorubicin against glioma cells in vitro and in vivo (reviewed recently in Gandhi et $\mathrm{al}^{98}$ ). miRNA-based molecules have also been used in combination with chemotherapeutic drugs in preclinical models through cationic LNPs or hyaluronic acid-chitosan nanoparticles. For example, the synergistic effect of miR-34a in combination with paclitaxel has been shown to inhibit growth of melanoma metastases to the lung, ${ }^{99}$ and growth of breast cancer when miR-34a was used in combination with doxorubicin. ${ }^{100} \mathrm{~A}$ polymer formulation has been developed to co-channel miR-205 and gemcitabine against pancreatic cancer. ${ }^{101-103}$ Intratumoral administration of these polyplexes in xenografted mice resulted in a significant reduction in the growth rate and weight of tumors compared with that in the control groups and showed a high biocompatibility of the micelles in vivo. ${ }^{104}$ Qian et al have synthesized new amphiphilic star-branched copolymers (PLA-PDMAEMA) for co-channeling of an inhibitor of miR-21 and doxorubicin into xenografts of glioma cells, leading to a significant synergistic inhibition of tumor growth ${ }^{105}$ and demonstrating the potential of the therapeutic combination.

These data suggest that use of molecules based on miRNA (miRNA mimics or anti-miRNAs) may intensify the therapeutic effects of chemotherapy drugs by specifically hitting crucial signaling pathways, thereby helping to enhance their efficacy and/or preventing resistance. Although not yet applied to HCC, the principles that miRNAs have established can open the way to studies for their application in $\mathrm{HCC}$ as well.

\section{Conclusion}

Knowledge of the role of miRNAs in HCC established the foundation for studying the antitumor activity of miRNA mimics or anti-miRNAs in HCC. These studies were made possible by the availability of animal models, induced either by use of carcinogens or by genetic modification. At least one of the existing models, the miRNA deregulation profile of which resembles that found in the human counterpart, ${ }^{47}$ may be adequate to investigate miRNA-based therapies. Still, some critical issues have also emerged. It is well known that human HCC occurs on a background of cirrhosis in $80 \%$ of cases, while this feature is generally not found in available animal models, which develop HCC in the absence of cirrhosis ${ }^{106}$ or develop cirrhosis but not HCC. ${ }^{106,107}$ Thus, models that could reproduce the natural history of human HCC could also improve preclinical studies aimed at prevention and treatment of HCC, possibly allowing the testing of new anticancer therapies on a cirrhotic background, which may help to limit failure in future clinical trials.

Another limitation of new therapies based on miRNA is the in vivo instability of the molecules. In addition to chemical modifications, a crucial point for therapy based on miRNAs is represented by the necessity of optimal delivery systems. Recent advances made in the field of nanocarriers have shown the way, ensuring greater protection of oligonucleotides and better targeted delivery to cancer cells, allowing more efficient transport of these molecules in vivo.

Several studies have also indicated that miRNAs can potentially sensitize cancer cells to chemotherapy. In vitro and in vivo evidence indicates increased therapeutic efficacy of the co-conveying miRNA/drug, suggesting a possible use of miRNAs in combination with drugs currently in clinical use. There are still no results for HCC, but available data are encouraging and the possibility of new systems for cochanneling miRNA/drug therapy against HCC with better characteristics in terms of efficacy or tolerability appears to be an important area of investigation.

\section{Acknowledgments}

This work was supported by funding from the Associazione Italiana per la Ricerca sul Cancro (AIRC IG15615) and from the University of Ferrara (FAR projects 2012-2013) to $\mathrm{MN}$.

\section{Disclosure}

The authors report no conflicts of interest in this work.

\section{References}

1. Parkin DM, Bray F, Ferlay J, Pisani P. Global cancer statistics, 2002. CA Cancer J Clin. 2005;55(2):74-108.

2. Llovet JM, Burroughs A, Bruix J. Hepatocellular carcinoma. Lancet. 2003;362(9399):1907-1917.

3. Bosch FX, Ribes J, Cleries R, Diaz M. Epidemiology of hepatocellular carcinoma. Clin Liver Dis. 2005;9(2):191-211. 
4. Farazi PA, DePinho RA. Hepatocellular carcinoma pathogenesis: from genes to environment. Nat Rev Cancer. 2006;6(9):674-687.

5. Purohit V, Rapaka R, Kwon OS, Song BJ. Roles of alcohol and tobacco exposure in the development of hepatocellular carcinoma. Life Sci. 2013;92(1):3-9.

6. Wu HC, Santella R. The role of aflatoxins in hepatocellular carcinoma. Hepat Mon. 2012;12(10 HCC):e7238.

7. Uccello M, Malaguarnera G, Corriere T, Biondi A, Basile F, Malaguarnera M. Risk of hepatocellular carcinoma in workers exposed to chemicals. Hepat Mon. 2012;12(10 HCC): e5943.

8. Starley BQ, Calcagno CJ, Harrison SA. Nonalcoholic fatty liver disease and hepatocellular carcinoma: a weighty connection. Hepatology. 2010;51(5):1820-1832.

9. Dragani TA. Risk of HCC: genetic heterogeneity and complex genetics. $J$ Hepatol. 2010;52(2):252-257.

10. Gramantieri L, Fornari F, Callegari E, et al. MicroRNA involvement in hepatocellular carcinoma. J Cell Mol Med. 2008;12(6A):2189-2204.

11. Guichard C, Amaddeo G, Imbeaud S, et al. Integrated analysis of somatic mutations and focal copy-number changes identifies key genes and pathways in hepatocellular carcinoma. Nat Genet. 2012;44(6): 694-698.

12. Kan Z, Zheng H, Liu X, et al. Whole-genome sequencing identifies recurrent mutations in hepatocellular carcinoma. Genome Res. 2013; 23(9):1422-1433.

13. Cleary SP, Jeck WR, Zhao X, et al. Identification of driver genes in hepatocellular carcinoma by exome sequencing. Hepatology. 2013;58(5): 1693-1702

14. Polakis P. Wnt signaling and cancer. Genes Dev. 2000;14(15): 1837-1851.

15. Fodde R, Brabletz T. Wnt/beta-catenin signaling in cancer stemness and malignant behavior. Curr Opin Cell Biol. 2007;19(2):150-158.

16. Vermeulen L, De Sousa EMF, van der Heijden M, et al. Wnt activity defines colon cancer stem cells and is regulated by the microenvironment. Nat Cell Biol. 2010;12(5):468-476.

17. Wend P, Holland JD, Ziebold U, Birchmeier W. Wnt signaling in stem and cancer stem cells. Semin Cell Dev Biol. 2010;21(8):855-863.

18. Thompson MD, Monga SP. WNT/beta-catenin signaling in liver health and disease. Hepatology. 2007;45(5):1298-1305.

19. Bruix J, Sherman M. Management of hepatocellular carcinoma. Hepatology. 2005;42(5):1208-1236.

20. Shrimal A, Prasanth M, Kulkarni AV. Interventional radiological treatment of hepatocellular carcinoma: an update. Indian J Surg. 2012;74(1): 91-99.

21. Llovet JM, Real MI, Montana X, et al. Arterial embolisation or chemoembolisation versus symptomatic treatment in patients with unresectable hepatocellular carcinoma: a randomised controlled trial. Lancet. 2002;359(9319):1734-1739.

22. Bruix J, Sherman M. Management of hepatocellular carcinoma: an update. Hepatology. 2011;53(3):1020-1022.

23. Llovet JM, Ricci S, Mazzaferro V, et al. Sorafenib in advanced hepatocellular carcinoma. $N$ Engl J Med. 2008;359(4):378-390.

24. Cheng AL, Kang YK, Chen Z, et al. Efficacy and safety of sorafenib in patients in the Asia-Pacific region with advanced hepatocellular carcinoma: a phase III randomised, double-blind, placebo-controlled trial. Lancet Oncol. 2009;10(1):25-34.

25. Wilhelm SM, Adnane L, Newell P, Villanueva A, Llovet JM, Lynch M. Preclinical overview of sorafenib, a multikinase inhibitor that targets both Raf and VEGF and PDGF receptor tyrosine kinase signaling. Mol Cancer Ther. 2008;7(10):3129-3140.

26. Bai W, Wang YJ, Zhao Y, et al. Sorafenib in combination with transarterial chemoembolization improves survival of unresectable hepatocellular carcinoma: a propensity-score matching study. $J$ Dig Dis. 2013;14(4):181-190.

27. Zhao Y, Wang WJ, Guan S, et al. Sorafenib combined with transarterial chemoembolization for the treatment of advanced hepatocellular carcinoma: a large-scale multicenter study of 222 patients. Ann Oncol. 2013;24(7):1786-1792.
28. Pawlik TM, Reyes DK, Cosgrove D, Kamel IR, Bhagat N, Geschwind JF. Phase II trial of sorafenib combined with concurrent transarterial chemoembolization with drug-eluting beads for hepatocellular carcinoma. J Clin Oncol. 2011;29(30):3960-3967.

29. Anestopoulos I, Voulgaridou GP, Georgakilas AG, Franco R, Pappa A, Panayiotidis MI. Epigenetic therapy as a novel approach in hepatocellular carcinoma. Pharmacol Ther. 2015;145:103-119.

30. Zhu AX, Kudo M, Assenat E, et al. Effect of everolimus on survival in advanced hepatocellular carcinoma after failure of sorafenib: the EVOLVE-1 randomized clinical trial. JAMA. 2014;312(1):57-67.

31. Llovet JM, Decaens T, Raoul JL, et al. Brivanib in patients with advanced hepatocellular carcinoma who were intolerant to sorafenib or for whom sorafenib failed: results from the randomized phase III BRISK-PS study. J Clin Oncol. 2013;31(28):3509-3516.

32. Cheng AL, Kang YK, Lin DY, et al. Sunitinib versus sorafenib in advanced hepatocellular cancer: results of a randomized phase III trial. J Clin Oncol. 2013;31(32):4067-4075.

33. Johnson PJ, Qin S, Park JW, et al. Brivanib versus sorafenib as firstline therapy in patients with unresectable, advanced hepatocellular carcinoma: results from the randomized phase III BRISK-FL study. J Clin Oncol. 2013;31(28):3517-3524.

34. Worns MA, Galle PR. HCC therapies - lessons learned. Nat Rev Gastroenterol Hepatol. 2014;11(7):447-452.

35. Negrini M, Gramantieri L, Sabbioni S, Croce CM. microRNA involvement in hepatocellular carcinoma. Anticancer Agents Med Chem. 2011; 11(6):500-521.

36. Li C, Wang Y, Wang S, et al. Hepatitis B virus mRNA-mediated miR-122 inhibition upregulates PTTG1-binding protein, which promotes hepatocellular carcinoma tumor growth and cell invasion. JVirol. 2013;87(4):2193-2205.

37. Xie KL, Zhang YG, Liu J, Zeng Y, Wu H. MicroRNAs associated with HBV infection and HBV-related HCC. Theranostics. 2014;4(12): 1176-1192.

38. Zheng J, Dong P, Gao S, Wang N, Yu F. High expression of serum miR-17-5p associated with poor prognosis in patients with hepatocellular carcinoma. Hepatogastroenterology. 2013;60(123):549-552.

39. Ringelhan M, O'Connor T, Protzer U, Heikenwalder M. The direct and indirect roles of $\mathrm{HBV}$ in liver cancer: prospective markers for $\mathrm{HCC}$ screening and potential therapeutic targets. J Pathol. 2015;235(2): 355-367.

40. Yuan K, Lian Z, Sun B, Clayton MM, Ng IO, Feitelson MA. Role of miR-148a in hepatitis B associated hepatocellular carcinoma. PLoS One. 2012;7(4):e35331.

41. Kumar A. MicroRNA in HCV infection and liver cancer. Biochim Biophys Acta. 2011;1809(11-12):694-699.

42. Banaudha K, Kaliszewski M, Korolnek T, et al. MicroRNA silencing of tumor suppressor DLC-1 promotes efficient hepatitis $\mathrm{C}$ virus replication in primary human hepatocytes. Hepatology. 2011;53(1):53-61.

43. Costinean S, Zanesi N, Pekarsky Y, et al. Pre-B cell proliferation and lymphoblastic leukemia/high-grade lymphoma in $\mathrm{E}(\mathrm{mu})$ miR155 transgenic mice. Proc Natl Acad Sci U S A. 2006;103(18): 7024-7029.

44. Santanam U, Zanesi N, Efanov A, et al. Chronic lymphocytic leukemia modeled in mouse by targeted miR-29 expression. Proc Natl Acad Sci US A. 2010;107(27):12210-12215.

45. Enomoto Y, Kitaura J, Hatakeyama K, et al. Emu/miR-125b transgenic mice develop lethal B-cell malignancies. Leukemia. 2011;25(12): 1849-1856.

46. Klein U, Lia M, Crespo M, et al. The DLEU2/miR-15a/16-1 cluster controls B cell proliferation and its deletion leads to chronic lymphocytic leukemia. Cancer Cell. 2010;17(1):28-40.

47. Callegari E, Elamin BK, Giannone F, et al. Liver tumorigenicity promoted by microRNA-221 in a mouse transgenic model. Hepatology. 2012;56(3):1025-1033.

48. Hsu SH, Wang B, Kota J, et al. Essential metabolic, anti-inflammatory, and anti-tumorigenic functions of miR-122 in liver. $J$ Clin Invest. 2012;122(8):2871-2883. 
49. Tsai WC, Hsu SD, Hsu CS, et al. MicroRNA-122 plays a critical role in liver homeostasis and hepatocarcinogenesis. J Clin Invest. 2012;122(8): 2884-2897.

50. Callegari E, Gramantieri L, Domenicali M, D’Abundo L, Sabbioni S, Negrini M. MicroRNAs in liver cancer: a model for investigating pathogenesis and novel therapeutic approaches. Cell Death Differ. 2015;22(1):46-57.

51. Yin H, Peng X, Ren P, Cheng B, Li S, Qin C. MicroRNAs as a novel class of diagnostic biomarkers in detection of hepatocellular carcinoma: a meta-analysis. Tumour Biol. 2014;35(12):12317-12326.

52. Cortez MA, Calin GA. MicroRNA identification in plasma and serum: a new tool to diagnose and monitor diseases. Expert Opin Biol Ther. 2009;9(6):703-711.

53. Qi J, Wang J, Katayama H, Sen S, Liu SM. Circulating microRNAs (cmiRNAs) as novel potential biomarkers for hepatocellular carcinoma. Neoplasma. 2013;60(2):135-142.

54. Callegari E, Elamin BK, Sabbioni S, Gramantieri L, Negrini M. Role of microRNAs in hepatocellular carcinoma: a clinical perspective. Onco Targets Ther. 2013;6:1167-1178.

55. Krutzfeldt J, Rajewsky N, Braich R, et al. Silencing of microRNAs in vivo with 'antagomirs'. Nature. 2005;438(7068):685-689.

56. Elmen J, Lindow M, Schutz S, et al. LNA-mediated microRNA silencing in non-human primates. Nature. 2008;452(7189):896-899.

57. Lindow M, Kauppinen S. Discovering the first microRNA-targeted drug. J Cell Biol. 2012;199(3):407-412.

58. Jopling CL, Yi M, Lancaster AM, Lemon SM, Sarnow P. Modulation of hepatitis $\mathrm{C}$ virus RNA abundance by a liver-specific microRNA. Science. 2005;309(5740):1577-1581.

59. Jopling CL. Regulation of hepatitis C virus by microRNA-122. Biochem Soc Trans. 2008;36 Pt 6:1220-1223.

60. Roberts AP, Lewis AP, Jopling CL. miR-122 activates hepatitis C virus translation by a specialized mechanism requiring particular RNA components. Nucleic Acids Res. 2011;39(17):7716-7729.

61. Gebert LF, Rebhan MA, Crivelli SE, Denzler R, Stoffel M, Hall J. Miravirsen (SPC3649) can inhibit the biogenesis of miR-122. Nucleic Acids Res. 2014;42(1):609-621.

62. Ottosen S, Parsley TB, Yang L, et al. Characterization of the in vitro antiviral activity and the preclinical and clinical resistance profile of miravirsen, a novel anti-HCV therapeutic targeting the human factor miR-122. Antimicrob Agents Chemother. 2015;59(1):599-608.

63. Ling H, Fabbri M, Calin GA. MicroRNAs and other non-coding RNAs as targets for anticancer drug development. Nat Rev Drug Discov. 2013; 12(11):847-865

64. Fornari F, Gramantieri L, Ferracin M, et al. MiR-221 controls CDKN1C/ p57 and CDKN1B/p27 expression in human hepatocellular carcinoma Oncogene. 2008;27(43):5651-5661.

65. Pineau P, Volinia S, McJunkin K, et al. miR-221 overexpression contributes to liver tumorigenesis. Proc Natl Acad Sci USA. 2010;107(1) 264-269

66. Park JK, Kogure T, Nuovo GJ, et al. miR-221 silencing blocks hepatocellular carcinoma and promotes survival. Cancer Res. 2011;71(24): 7608-7616.

67. Kota J, Chivukula RR, O'Donnell KA, et al. Therapeutic microRNA delivery suppresses tumorigenesis in a murine liver cancer model. Cell. 2009;137(6):1005-1017.

68. Hou J, Lin L, Zhou W, et al. Identification of miRNomes in human liver and hepatocellular carcinoma reveals miR-199a/b-3p as therapeutic target for hepatocellular carcinoma. Cancer Cell. 2011;19(2):232-243.

69. Bader AG. miR-34 - a microRNA replacement therapy is headed to the clinic. Front Genet. 2012;3:120.

70. Kelnar K, Peltier HJ, Leatherbury N, Stoudemire J, Bader AG. Quantification of therapeutic miRNA mimics in whole blood from nonhuman primates. Anal Chem. 2014;86(3):1534-1542.

71. Ylosmaki E, Hakkarainen T, Hemminki A, Visakorpi T, Andino R, Saksela K. Generation of a conditionally replicating adenovirus based on targeted destruction of E1A mRNA by a cell type-specific microRNA. J Virol. 2008;82(22):11009-11015.
72. Cawood R, Chen HH, Carroll F, Bazan-Peregrino M, van Rooijen N, Seymour LW. Use of tissue-specific microRNA to control pathology of wild-type adenovirus without attenuation of its ability to kill cancer cells. PLoS Pathog. 2009;5(5):e1000440.

73. Jin H, Lv S, Yang J, et al. Use of microRNA Let-7 to control the replication specificity of oncolytic adenovirus in hepatocellular carcinoma cells. PLoS One. 2011;6(7):e21307.

74. Callegari E, Elamin BK, D'Abundo L, et al. Anti-tumor activity of a miR199-dependent oncolytic adenovirus. PLoS One. 2013;8(9):e73964.

75. Zhou C, Yang Z, Teng L. Nanomedicine based on nucleic acids: pharmacokinetic and pharmacodynamic perspectives. Curr Pharm Biotechnol. 2014;15(9):829-838.

76. Matsumura Y, Maeda H. A new concept for macromolecular therapeutics in cancer chemotherapy: mechanism of tumoritropic accumulation of proteins and the antitumor agent smancs. Cancer Res. 1986;46(12 Pt 1): 6387-6392.

77. Zimmermann TS, Lee AC, Akinc A, et al. RNAi-mediated gene silencing in non-human primates. Nature. 2006;441(7089):111-114.

78. Frank-Kamenetsky M, Grefhorst A, Anderson NN, et al. Therapeutic RNAi targeting PCSK9 acutely lowers plasma cholesterol in rodents and LDL cholesterol in nonhuman primates. Proc Natl Acad Sci USA. 2008;105(33):11915-11920.

79. Shu Y, Pi F, Sharma A, et al. Stable RNA nanoparticles as potential new generation drugs for cancer therapy. Adv Drug Deliv Rev. 2014;66: 74-89.

80. Hatziapostolou M, Polytarchou C, Aggelidou E, et al. An HNF4alphamiRNA inflammatory feedback circuit regulates hepatocellular oncogenesis. Cell. 2011;147(6):1233-1247.

81. Trang P, Wiggins JF, Daige CL, et al. Systemic delivery of tumor suppressor microRNA mimics using a neutral lipid emulsion inhibits lung tumors in mice. Mol Ther. 2011;19(6):1116-1122.

82. Hsu SH, Yu B, Wang X, et al. Cationic lipid nanoparticles for therapeutic delivery of siRNA and miRNA to murine liver tumor. Nanomedicine. 2013;9(8):1169-1180

83. Wang X, Yu B, Ren W, et al. Enhanced hepatic delivery of siRNA and microRNA using oleic acid based lipid nanoparticle formulations. J Control Release. 2013;172(3):690-698.

84. Tabernero J, Shapiro GI, LoRusso PM, et al. First-in-humans trial of an RNA interference therapeutic targeting VEGF and KSP in cancer patients with liver involvement. Cancer Discov. 2013;3(4):406-417.

85. Iyer AK, Duan Z,Amiji MM. Nanodelivery systems for nucleic acid therapeutics in drug resistant tumors. Mol Pharm. 2014;11(8):2511-2526.

86. Chen Y, Zhu X, Zhang X, Liu B, Huang L. Nanoparticles modified with tumor-targeting scFv deliver siRNA and miRNA for cancer therapy. Mol Ther. 2010;18(9):1650-1656.

87. Tivnan A, Orr WS, Gubala V, et al. Inhibition of neuroblastoma tumor growth by targeted delivery of microRNA-34a using anti-disialoganglioside GD2 coated nanoparticles. PLoS One. 2012;7(5):e38129.

88. Su J, Baigude H, McCarroll J, Rana TM. Silencing microRNA by interfering nanoparticles in mice. Nucleic Acids Res. 2011;39(6):e38.

89. Baigude $\mathrm{H}$, Rana TM. Interfering nanoparticles for silencing microRNAs. Methods Enzymol. 2012;509:339-353.

90. Sato Y, Hatakeyama H, Sakurai Y, Hyodo M, Akita H, Harashima H. A pH-sensitive cationic lipid facilitates the delivery of liposomal siRNA and gene silencing activity in vitro and in vivo. $J$ Control Release. 2012;163(3):267-276.

91. Takahashi M, Yamada N, Hatakeyama H, et al. In vitro optimization of 2'-OMe-4'-thioribonucleoside-modified anti-microRNA oligonucleotides and its targeting delivery to mouse liver using a liposomal nanoparticle. Nucleic Acids Res. 2013;41(22):10659-10667.

92. Zhang M, Zhou X, Wang B, et al. Lactosylated gramicidin-based lipid nanoparticles (Lac-GLN) for targeted delivery of anti-miR-155 to hepatocellular carcinoma. J Control Release. 2013;168(3): 251-261.

93. Fornari F, Milazzo M, Chieco P, et al. MiR-199a-3p regulates mTOR and c-Met to influence the doxorubicin sensitivity of human hepatocarcinoma cells. Cancer Res. 2010;70(12):5184-5193. 
94. Zhao N, Wang R, Zhou L, Zhu Y, Gong J, Zhuang SM. MicroRNA-26b suppresses the NF-kappaB signaling and enhances the chemosensitivity of hepatocellular carcinoma cells by targeting TAK1 and TAB3. Mol Cancer. 2014;13:35.

95. Bai S, Nasser MW, Wang B, et al. MicroRNA-122 inhibits tumorigenic properties of hepatocellular carcinoma cells and sensitizes these cells to sorafenib. J Biol Chem. 2009;284(46):32015-32027.

96. Fornari F, Gramantieri L, Giovannini C, et al. MiR-122/cyclin G1 interaction modulates p53 activity and affects doxorubicin sensitivity of human hepatocarcinoma cells. Cancer Res. 2009;69(14): 5761-5767.

97. Yang F, Li QJ, Gong ZB, et al. MicroRNA-34a targets Bcl-2 and sensitizes human hepatocellular carcinoma cells to sorafenib treatment. Technol Cancer Res Treat. 2014;13(1):77-86.

98. Gandhi NS, Tekade RK, Chougule MB. Nanocarrier mediated delivery of siRNA/miRNA in combination with chemotherapeutic agents for cancer therapy: current progress and advances. $J$ Control Release. 2014;194C:238-256.

99. Shi S, Han L, Deng L, et al. Dual drugs (microRNA-34a and paclitaxel)loaded functional solid lipid nanoparticles for synergistic cancer cell suppression. J Control Release. 2014;194C:228-237.

100. Deng X, Cao M, Zhang J, et al. Hyaluronic acid-chitosan nanoparticles for co-delivery of MiR-34a and doxorubicin in therapy against triple negative breast cancer. Biomaterials. 2014;35(14):4333-4344.

101. Wang N, Li Q, Feng NH, et al. miR-205 is frequently downregulated in prostate cancer and acts as a tumor suppressor by inhibiting tumor growth. Asian J Androl. 2013;15(6):735-741.

102. Singh S, Chitkara D, Kumar V, Behrman SW, Mahato RI. miRNA profiling in pancreatic cancer and restoration of chemosensitivity. Cancer Lett. 2013;334(2):211-220.

103. Von Hoff DD, Ervin T, Arena FP, et al. Increased survival in pancreatic cancer with nab-paclitaxel plus gemcitabine. N Engl J Med. 2013; 369(18):1691-1703.

104. Mittal A, Chitkara D, Behrman SW, Mahato RI. Efficacy of gemcitabine conjugated and miRNA-205 complexed micelles for treatment of advanced pancreatic cancer. Biomaterials. 2014;35(25): 7077-7087.

105. Qian X, Long L, Shi Z, et al. Star-branched amphiphilic PLA-bPDMAEMA copolymers for co-delivery of miR-21 inhibitor and doxorubicin to treat glioma. Biomaterials. 2014;35(7):2322-2335.

106. Fujii T, Fuchs BC, Yamada S, et al. Mouse model of carbon tetrachloride induced liver fibrosis: Histopathological changes and expression of CD133 and epidermal growth factor. BMC Gastroenterol. 2010;10:79.

107. Domenicali M, Caraceni P, Giannone F, et al. A novel model of CCl4induced cirrhosis with ascites in the mouse. J Hepatol. 2009;51(6): 991-999.

108. Mercatelli N, Coppola V, Bonci D, et al. The inhibition of the highly expressed miR-221 and miR-222 impairs the growth of prostate carcinoma xenografts in mice. PLoS One. 2008;3(12):e4029.

109. Felicetti F, Errico MC, Bottero L, et al. The promyelocytic leukemia zinc finger-microRNA-221/-222 pathway controls melanoma progression through multiple oncogenic mechanisms. Cancer Res. 2008;68(8): 2745-2754.

110. Di Martino MT, Gulla A, Cantafio ME, et al. In vitro and in vivo anti-tumor activity of miR-221/222 inhibitors in multiple myeloma. Oncotarget. 2013;4(2):242-255.

111. Lim L, Balakrishnan A, Huskey N, et al. MiR-494 within an oncogenic MicroRNA megacluster regulates G1/S transition in liver tumorigenesis through suppression of MCC. Hepatology. 2014;59(1):202-215.

112. Kitade Y, Akao Y. MicroRNAs and their therapeutic potential for human diseases: microRNAs, miR-143 and -145, function as antioncomirs and the application of chemically modified miR-143 as an anti-cancer drug. J Pharmacol Sci. 2010;114(3):276-280.

113. Su H, Yang JR, Xu T, et al. MicroRNA-101, down-regulated in hepatocellular carcinoma, promotes apoptosis and suppresses tumorigenicity. Cancer Res. 2009;69(3):1135-1142.
114. Xiong Y, Fang JH, Yun JP, et al. Effects of microRNA-29 on apoptosis, tumorigenicity, and prognosis of hepatocellular carcinoma. Hepatology. 2010;51(3):836-845.

115. Jia XQ, Cheng HQ, Qian X, et al. Lentivirus-mediated overexpression of microRNA-199a inhibits cell proliferation of human hepatocellular carcinoma. Cell Biochem Biophys. 2012;62(1): 237-244.

116. He XX, Chang Y, Meng FY, et al. MicroRNA-375 targets AEG-1 in hepatocellular carcinoma and suppresses liver cancer cell growth in vitro and in vivo. Oncogene. 2012;31(28):3357-3369.

117. Valastyan S, Chang A, Benaich N, Reinhardt F, Weinberg RA. Activation of miR-31 function in already-established metastases elicits metastatic regression. Genes Dev. 2011;25(6):646-659.

118. Di Martino MT, Leone E, Amodio N, et al. Synthetic miR-34a mimics as a novel therapeutic agent for multiple myeloma: in vitro and in vivo evidence. Clin Cancer Res. 2012;18(22):6260-6270.

119. Trang P, Medina PP, Wiggins JF, et al. Regression of murine lung tumors by the let-7 microRNA. Oncogene. 2010;29(11): 1580-1587.

120. Zhang J, Yang Y, Yang T, et al. A double-negative feedback loop between MicroRNA-422a and FOXG1/Q1/E1 regulates hepatocellular carcinoma tumor growth and metastasis. Hepatology. 2015;61(2): 561-573.

121. Edge RE, Falls TJ, Brown CW, Lichty BD, Atkins H, Bell JC. A let-7 MicroRNA-sensitive vesicular stomatitis virus demonstrates tumorspecific replication. Mol Ther. 2008;16(8):1437-1443.

122. Hikichi M, Kidokoro M, Haraguchi T, et al. MicroRNA regulation of glycoprotein B5R in oncolytic vaccinia virus reduces viral pathogenicity without impairing its antitumor efficacy. Mol Ther. 2011;19(6):1107-1115.

123. Cawood R, Wong SL, Di Y, Baban DF, Seymour LW. MicroRNA controlled adenovirus mediates anti-cancer efficacy without affecting endogenous microRNA activity. PLoS One. 2011;6(1):e16152.

124. Ylosmaki E, Lavilla-Alonso S, Jaamaa S, et al. MicroRNA-mediated suppression of oncolytic adenovirus replication in human liver. PLoS One. 2013;8(1):e54506.

125. Lee CY, Rennie PS, Jia WW. MicroRNA regulation of oncolytic herpes simplex virus-1 for selective killing of prostate cancer cells. Clin Cancer Res. 2009;15(16):5126-5135.

126. Fu X, Rivera A, Tao L, De Geest B, Zhang X. Construction of an oncolytic herpes simplex virus that precisely targets hepatocellular carcinoma cells. Mol Ther. 2012;20(2):339-346.

127. Leber MF, Bossow S, Leonard VH, et al. MicroRNA-sensitive oncolytic measles viruses for cancer-specific vector tropism. Mol Ther. 2011;19(6):1097-1106.

128. Kelly EJ, Hadac EM, Greiner S, Russell SJ. Engineering microRNA responsiveness to decrease virus pathogenicity. Nat Med. 2008;14(11): 1278-1283.

129. Mazzacurati L, Marzulli M, Reinhart B, et al. Use of miRNA response sequences to block off-target replication and increase the safety of an unattenuated, glioblastoma-targeted oncolytic HSV. Mol Ther. 2015; 23(1):99-107.

130. Yao W, Guo G, Zhang Q, Fan L, Wu N, Bo Y. The application of multiple miRNA response elements enables oncolytic adenoviruses to possess specificity to glioma cells. Virology. 2014;458-459: 69-82.

131. Budhu A, Jia HL, Forgues M, et al. Identification of metastasis-related microRNAs in hepatocellular carcinoma. Hepatology. 2008;47(3): 897-907.

132. Jiang J, Gusev Y, Aderca I, et al. Association of microRNA expression in hepatocellular carcinomas with hepatitis infection, cirrhosis, and patient survival. Clin Cancer Res. 2008;14(2):419-427.

133. Han ZB, Zhong L, Teng MJ, et al. Identification of recurrencerelated microRNAs in hepatocellular carcinoma following liver transplantation. Mol Oncol. 2012;6(4):445-457.

134. Ji J, Shi J, Budhu A, et al. MicroRNA expression, survival, and response to interferon in liver cancer. $N$ Engl J Med. 2009;361(15): $1437-1447$. 
135. Coulouarn C, Factor VM, Andersen JB, Durkin ME, Thorgeirsson SS. Loss of miR-122 expression in liver cancer correlates with suppression of the hepatic phenotype and gain of metastatic properties. Oncogene. 2009;28(40):3526-3536.

136. Tsai WC, Hsu PW, Lai TC, et al. MicroRNA-122, a tumor suppressor microRNA that regulates intrahepatic metastasis of hepatocellular carcinoma. Hepatology. 2009;49(5):1571-1582.

137. Viswanathan SR, Powers JT, Einhorn W, et al. Lin 28 promotes transformation and is associated with advanced human malignancies. Nat Genet. 2009;41(7):843-848.

138. Wang C, Song B, Song W, et al. Underexpressed microRNA-199b-5p targets hypoxia-inducible factor-1alpha in hepatocellular carcinoma and predicts prognosis of hepatocellular carcinoma patients. J Gastroenterol Hepatol. 2011;26(11):1630-1637.

139. Zhang Y, Guo X, Xiong L, et al. MicroRNA-101 suppresses SOX9dependent tumorigenicity and promotes favorable prognosis of human hepatocellular carcinoma. FEBS Lett. 2012;586(24):4362-4370.

140. Li W, Xie L, He X, et al. Diagnostic and prognostic implications of microRNAs in human hepatocellular carcinoma. Int $J$ Cancer. 2008;123(7):1616-1622.

141. Murakami Y, Yasuda T, Saigo K, et al. Comprehensive analysis of microRNA expression patterns in hepatocellular carcinoma and nontumorous tissues. Oncogene. 2006;25(17):2537-2545.

142. Gu H, Guo X, Zou L, Zhu H, Zhang J. Upregulation of microRNA372 associates with tumor progression and prognosis in hepatocellular carcinoma. Mol Cell Biochem. 2013;375(1-2):23-30.

143. Gramantieri L, Fornari F, Ferracin M, et al. MicroRNA-221 targets Bmf in hepatocellular carcinoma and correlates with tumor multifocality. Clin Cancer Res. 2009;15(16):5073-5081.

144. Fu X, Wang Q, Chen J, et al. Clinical significance of miR-221 and its inverse correlation with $\mathrm{p} 27 \mathrm{Kip}(1)$ in hepatocellular carcinoma. Mol Biol Rep. 2011;38(5):3029-3035.

145. Rong M, Chen G, Dang Y. Increased miR-221 expression in hepatocellular carcinoma tissues and its role in enhancing cell growth and inhibiting apoptosis in vitro. BMC Cancer. 2013;13:21.

146. Chen L, Jiang M, Yuan W, Tang H. miR-17-5p as a novel prognostic marker for hepatocellular carcinoma. J Invest Surg. 2012;25(3): 156-161.

147. Han ZB, Chen HY, Fan JW, Wu JY, Tang HM, Peng ZH. Up-regulation of microRNA-155 promotes cancer cell invasion and predicts poor survival of hepatocellular carcinoma following liver transplantation. J Cancer Res Clin Oncol. 2012;138(1):153-161.

148. Chen HY, Han ZB, Fan JW, et al. miR-203 expression predicts outcome after liver transplantation for hepatocellular carcinoma in cirrhotic liver. Med Oncol. 2012;29(3):1859-1865.

149. Murakami Y, Tamori A, Itami S, et al. The expression level of miR-18b in hepatocellular carcinoma is associated with the grade of malignancy and prognosis. BMC Cancer. 2013;13:99.

150. Fan MQ, Huang CB, Gu Y, Xiao Y, Sheng JX, Zhong L. Decrease expression of microRNA-20a promotes cancer cell proliferation and predicts poor survival of hepatocellular carcinoma. J Exp Clin Cancer Res. 2013;32(1):21

151. Zhi Q, Zhu J, Guo X, et al. Metastasis-related miR-185 is a potential prognostic biomarker for hepatocellular carcinoma in early stage. Biomed Pharmacother. 2013;67(5):393-398.

152. Rong M, He R, Dang Y, Chen G. Expression and clinicopathological significance of miR-146a in hepatocellular carcinoma tissues. Ups $J$ Med Sci. 2014;119(1):19-24.

153. Li T, Yin J, Yuan L, et al. Downregulation of microRNA-139 is associated with hepatocellular carcinoma risk and short-term survival. Oncol Rep. 2014;31(4):1699-1706.

154. Su ZX, Zhao J, Rong ZH, Geng WM, Wu YG, Qin CK. Upregulation of microRNA-25 associates with prognosis in hepatocellular carcinoma. Diagn Pathol. 2014;9:47.

155. Xu J, Zhu X, Wu L, et al. MicroRNA-122 suppresses cell proliferation and induces cell apoptosis in hepatocellular carcinoma by directly targeting Wnt/beta-catenin pathway. Liver Int. 2012;32(5):752-760.
156. Cermelli S, Ruggieri A, Marrero JA, Ioannou GN, Beretta L. Circulating microRNAs in patients with chronic hepatitis $\mathrm{C}$ and nonalcoholic fatty liver disease. PLoS One. 2011;6(8):e23937.

157. Trebicka J, Anadol E, Elfimova N, et al. Hepatic and serum levels of miR-122 after chronic HCV-induced fibrosis. J Hepatol. 2013;58(2): 234-239.

158. van der Meer AJ, Farid WR, Sonneveld MJ, et al. Sensitive detection of hepatocellular injury in chronic hepatitis $\mathrm{C}$ patients with circulating hepatocyte-derived microRNA-122. J Viral Hepat. 2013;20(3): 158-166.

159. Qi P, Cheng SQ, Wang H, Li N, Chen YF, Gao CF. Serum microRNAs as biomarkers for hepatocellular carcinoma in Chinese patients with chronic hepatitis B virus infection. PLoS One. 2011;6(12):e28486.

160. Xu J, Wu C, Che X, et al. Circulating microRNAs, miR-21, miR-122, and miR-223, in patients with hepatocellular carcinoma or chronic hepatitis. Mol Carcinog. 2011;50(2):136-142.

161. Tomimaru Y, Eguchi H, Nagano H, et al. Circulating microRNA-21 as a novel biomarker for hepatocellular carcinoma. J Hepatol. 2012;56(1): $167-175$

162. Li J, Wang Y, Yu W, Chen J, Luo J. Expression of serum miR-221 in human hepatocellular carcinoma and its prognostic significance. Biochem Biophys Res Commun. 2011;406(1):70-73.

163. Gui J, Tian Y, Wen X, et al. Serum microRNA characterization identifies miR-885-5p as a potential marker for detecting liver pathologies Clin Sci (Lond). 2011;120(5):183-193.

164. Liu AM, Yao TJ, Wang W, et al. Circulating miR-15b and miR-130b in serum as potential markers for detecting hepatocellular carcinoma: a retrospective cohort study. BMJ Open. 2012;2(2):e000825.

165. Shrivastava S, Petrone J, Steele R, Lauer GM, Bisceglie AM, Ray RB. Upregulation of circulating miR-20a is correlated with hepatitis $\mathrm{C}$ virus mediated liver disease progression. Hepatology. 2013;58(3): 863-871.

166. Li L, Guo Z, Wang J, Mao Y, Gao Q. Serum miR-18a: a potential marker for hepatitis B virus-related hepatocellular carcinoma screening. Dig Dis Sci. 2012;57(11):2910-2916.

167. Fu Y, Wei X, Tang C, et al. Circulating microRNA-101 as a potential biomarker for hepatitis B virus-related hepatocellular carcinoma. Oncol Lett. 2013;6(6):1811-1815.

168. Xie Y, Yao Q, Butt AM, et al. Expression profiling of serum microRNA-101 in HBV-associated chronic hepatitis, liver cirrhosis, and hepatocellular carcinoma. Cancer Biol Ther. 2014;15(9): 1248-1255.

169. Giray BG, Emekdas G, Tezcan S, et al. Profiles of serum microRNAs; miR-125b-5p and miR223-3p serve as novel biomarkers for HBV-positive hepatocellular carcinoma. Mol Biol Rep. 2014;41(7): 4513-4519.

170. Ge W, Yu DC, Li QG, Chen X, Zhang CY, Ding YT. Expression of serum miR-16, let-7f, and miR-21 in patients with hepatocellular carcinoma and their clinical significances. Clin Lab. 2014;60(3): $427-434$.

171. Wang H, Hou L, Li A, Duan Y, Gao H, Song X. Expression of serum exosomal microRNA-21 in human hepatocellular carcinoma. Biomed Res Int. 2014;2014:864894.

172. Zhang ZQ, Meng H, Wang N, et al. Serum microRNA 143 and microRNA 215 as potential biomarkers for the diagnosis of chronic hepatitis and hepatocellular carcinoma. Diagn Pathol. 2014;9:135.

173. Liu M, Liu J, Wang L, et al. Association of serum microRNA expression in hepatocellular carcinomas treated with transarterial chemoembolization and patient survival. PLoS One. 2014;9(10): e109347.

174. Yin J, Hou P, Wu Z, Wang T, Nie Y. Circulating miR-375 and miR-199a-3p as potential biomarkers for the diagnosis of hepatocellular carcinoma. Tumour Biol. January 25, 2015. [Epub ahead of print.]

175. Leone E, Morelli E, Di Martino MT, et al. Targeting miR-21 inhibits in vitro and in vivo multiple myeloma cell growth. Clin Cancer Res. 2013;19(8):2096-2106. 
176. Babar IA, Cheng CJ, Booth CJ, et al. Nanoparticle-based therapy in an in vivo microRNA-155 (miR-155)-dependent mouse model of lymphoma. Proc Natl Acad Sci U S A. 2012;109(26):E1695-E1704.

177. Liu XQ, Song WJ, Sun TM, Zhang PZ, Wang J. Targeted delivery of antisense inhibitor of miRNA for antiangiogenesis therapy using cRGD-functionalized nanoparticles. Mol Pharm. 2011;8(1): 250-259.

178. Kasinski AL, Slack FJ. miRNA-34 prevents cancer initiation and progression in a therapeutically resistant K-ras and p53-induced mouse model of lung adenocarcinoma. Cancer Res. 2012;72(21): 5576-5587.

179. Wu Y, Crawford M, Mao Y, et al. Therapeutic delivery of microRNA-29b by cationic lipoplexes for lung cancer. Mol Ther Nucleic Acids. 2013;2:e84.
180. Huang X, Schwind S, Yu B, et al. Targeted delivery of microRNA-29b by transferrin-conjugated anionic lipopolyplex nanoparticles: a novel therapeutic strategy in acute myeloid leukemia. Clin Cancer Res. 2013; 19(9):2355-2367.

181. Ibrahim AF, Weirauch U, Thomas M, Grunweller A, Hartmann RK, Aigner A. MicroRNA replacement therapy for miR-145 and miR-33a is efficacious in a model of colon carcinoma. Cancer Res. 2011;71(15): 5214-5224.

182. Akao Y, Nakagawa Y, Hirata I, et al. Role of anti-oncomirs miR-143 and -145 in human colorectal tumors. Cancer Gene Ther. 2010;17(6): 398-408.

183. Babae N, Bourajjaj M, Liu Y, et al. Systemic miRNA-7 delivery inhibits tumor angiogenesis and growth in murine xenograft glioblastoma. Oncotarget. 2014;5(16):6687-6700.

\section{Publish your work in this journal}

Gastrointestinal Cancer: Targets and Therapy is an international, peer-reviewed, open access journal focusing on gastro-intestinal cancer research, identification of therapeutic targets and the optimal use of preventative and integrated treatment interventions to achieve improved outcomes, enhanced survival and quality of life for the cancer patient. The manuscript management system is completely online and includes a very quick and fair peer-review system. Visit http://www.dovepress.com/testimonials.php to read real quotes from published authors.

Submit your manuscript here: http://www.dovepress.com/gastro-intestinal-cancer-targets-and-therapy-journal 